University of Nebraska - Lincoln

DigitalCommons@University of Nebraska - Lincoln

Virology Papers

Virology, Nebraska Center for

$1-1988$

Reliable Detection of Individuals Seropositive for the Human

Immunodeficiency Virus (HIV) by Competitive Immunoassays

Using Escherichia coli - Expressed HIV Structural Proteins

G. J. Dawson

Hepatitis/AIDS Research Department, Abbott Laboratories, North Chicago, Illinois

J. S. Heller

Hepatitis/AIDS Research Department, Abbott Laboratories, North Chicago, Illinois

Charles Wood

University of Nebraska-Lincoln, cwood1@unl.edu

R. A. Gutierrez

Hepatitis/AIDS Research Department, Abbott Laboratories, North Chicago, Illinois

J. S. Webber

Hepatitis/AIDS Research Department, Abbott Laboratories, North Chicago, Illinois

See next page for additional authors

Follow this and additional works at: https://digitalcommons.unl.edu/virologypub

Part of the Virology Commons

Dawson, G. J.; Heller, J. S.; Wood, Charles; Gutierrez, R. A.; Webber, J. S.; Hunt, J. C.; Hojvat, S. A.; Senn, D.; Devare, S. G.; and Decker, R. H., "Reliable Detection of Individuals Seropositive for the Human Immunodeficiency Virus (HIV) by Competitive Immunoassays Using Escherichia coli - Expressed HIV Structural Proteins" (1988). Virology Papers. 181.

https://digitalcommons.unl.edu/virologypub/181

This Article is brought to you for free and open access by the Virology, Nebraska Center for at DigitalCommons@University of Nebraska - Lincoln. It has been accepted for inclusion in Virology Papers by an authorized administrator of DigitalCommons@University of Nebraska - Lincoln. 


\section{Authors}

G. J. Dawson, J. S. Heller, Charles Wood, R. A. Gutierrez, J. S. Webber, J. C. Hunt, S. A. Hojvat, D. Senn, S. G. Devare, and R. H. Decker 


\title{
Reliable Detection of Individuals Seropositive for the Human Immunodeficiency Virus (HIV) by Competitive Immunoassays Using Escherichia coli-Expressed HIV Structural Proteins
}

\author{
G. J. Dawson, J. S. Heller, C. A. Wood, \\ R. A. Gutierrez, J. S. Webber, J. C. Hunt, \\ S. A. Hojvat, D. Senn, S. G. Devare, and \\ R. H. Decker
}

From the Hepatitis/AIDS Research Department, Abbott

Laboratories, North Chicago, Illinois

\begin{abstract}
We molecularly cloned the gag and env genes of the human immunodeficiency virus (HIV) and expressed fragments of these genes in Escherichia coli. Using the recombinant core and envelope proteins, we developed two competitive immunoassays (CIAs). Samples that recognized either the envelope or core proteins were considered positive for antibodies to HIV. This test system was comparable with western blot in detecting antibodies in patients with AIDS or AIDS-related complex that were repeatably reactive in the HIV screening test. All 360 individuals who were positive by western blot were positive by the CIA. A total of 844 samples repeatably reactive by an ELISA screening test were negative both by western blot and by the CIA; 48 samples positive by ELISA, but negative or indeterminate by western blot, were positive by the CIA. Alternate research procedures verified the positivity of these individuals. These data indicate that the CIA described here may be useful as an adjunct or alternative to the western blot.
\end{abstract}

Although the blood screening tests for detecting antibodies to the human immunodeficiency virus (HIV; formerly known as HTLV-III or LAV) have been effective in identifying potentially infectious blood donors $[1,2]$, false-positive results do occur [3, 4]; it is therefore necessary to confirm the presence of antibody to HIV with a reliable, alternate immunologic test. The western blot is currently the test-ofchoice as the alternate procedure. Western blot differs from the screening test in that it includes electrophoretically separated $\mathrm{HIV}$ antigens attached to a solid phase; thus virus-specific antibodies in the reactive serum can be identified with greater confidence. Like the screening tests, however, the western blot works by an antibody-capture principle, and false-positive results may occur with samples containing antibodies to contaminating, nonviral proteins or with samples containing immunoglobulins that bind nonspecifically to nitrocellulose [5-8]. Moreover, the western blot is subjective in nature. It is difficult to assess the specificity and sensitivity of the western blot in the same manner as a solid-phase ELISA in

Received for publication 19 March 1987, and in revised form 27 July 1987.

Please address requests for reprints to Dr. George J. Dawson, Hepatitis/AIDS Research, Abbott Diagnostics Division, Abbott Laboratories, North Chicago, Illinois 60064 . which a numerical value allows discrimination between reactive and nonreactive samples.

In this report, we demonstrate the efficacy of a quantifiable solid-phase competitive immunoassay (CIA) system (commercially available in Europe as Envacor ${ }^{\circledR}$; Abbott Laboratories, North Chicago, III) that uses recombinant antigens and that can be used to confirm a positive result for HIV screening tests. This system consists of two separate immunoassays, one designed to detect antibodies to HIV gag gene products (core proteins) and the other to detect antibodies to HIV env gene products (envelope proteins). The antigens used in this immunoassay system were produced as recombinant DNA-derived proteins expressed in Escherichia coli. These assays provide independent determinations of the antibody response to the core and envelope proteins [9] and are highly specific and sensitive as compared with other established assays. This immunoassay system provides a testing procedure that could be used as a reliable alternative to the western blot for confirming antibody to HIV in sera.

\section{Materials and Methods}

Cloning and expression of HIV core and envelope proteins. HIV-infected HT 9 cells were obtained from the National Cancer Institute (Bethesda, Md). 
High-molecular-weight DNA was extracted from infected cells by using the standard procedure [10]. The DNA was partially digested by EcoRI and cloned into the EcoRI site of Charon $4 \mathrm{~A}$, a derivative of bacteriophage $\lambda$ [11]. A recombinant library of $10^{6}$ phages was screened with HIV cDNA, and clones containing integrated proviral sequences were characterized and sequenced as described [12].

Segments encoding the gag gene included all of the amino acid residues of 24 as well as the $\mathrm{COOH}$ the amina acid terminal amide a terminal amino acids of p15. Segments encoding the env gene included all of the amino acid residues of $\mathrm{gp} 41$ and the COOH-terminal amino acid residues of gp120. These segments were subcloned into the pUC 9 vector for expression of specific HIV proteins [13]. Expression of the cloned antigens was induced with isopropyl $\beta$-D-thiogalactopyranoside when the bacteria reached mid-log phase growth. After induction for $2 \mathrm{~h}$, the bacteria were lysed by sonication as described [14].

$C I A$. Human IgG antibodies to HIV were purified by anion-exchange chromatography from human sera rich in man sera in in scribed previon in ads coated with the HIV IgG, then exposed to a preparation of recombinant proteins containing either the envelope or core recombinant antigens. Additional IgG preparations from other seropositive individuals were conjugated with horseradish peroxidase (HRP) according to a modification of the procedure of Nakane et al. [16] and were diluted appropriately. The CIA for the envelope protein was initiated by adding test serum or plasma $(50 \mu \mathrm{L})$ to specimen diluent $(20 \mu \mathrm{L})$ in a reaction well; $200 \mu \mathrm{L}$ of diluted HRP-labeled human ISG antibodies to HIV envelope proteins were then added. A polystyrene bead lo coated whetein was added. HRP-conjugated IgG and test samples were allowed to compete for binding to envelope protein overnight $(16-22 \mathrm{~h})$ at room temperature $(\sim 25 \mathrm{C})$. The beads were then washed three times with distilled water $(5 \mathrm{~mL} /$ wash) by using a Pentawash ${ }^{\boxplus}$. (Abbott Laboratories, Dallas). The amount of bound HRP-conjugated IgG was determined by adding, per bead, $300 \mu \mathrm{L}$ of a solution of $0.3 \% o$-phenylenediamine $-2 \mathrm{HCl}$ in $0.1 \mathrm{M}$ citrate buffer ( $\mathrm{pH} 5.5$ ) with $0.02 \% \mathrm{H}_{2} \mathrm{O}_{2}$. After $30 \mathrm{~min}$ of incubation at room temperature the reaction was terminated by the addition of $1 \mathrm{NH}_{2} \mathrm{SO}_{4}$. The color produced was inversely proportional to the amount of HIV antibody present in the test sample. The $A_{492}$ was read on a spectrophotometer. A cutoff value was established as a function of both the positive and negative mean control values and was calculated as the sum of the control values divided by 2 . The CIA for the core protein was performed in the same manner, except that HRP-labeled human IgG antibodies to the core protein and polystyrene beads coated with recorbint and and nith each run. Pasitue samples containing antibodies to the HIV envelope or core recombinant proteins competed efficiently with the HRP-labeled antibodies for binding sites on the recombinant antigen bound to the solid phase. Samples having absorbance values equal to or less than the cutoff value were considered positive for antibodies to HIV. A sample reactive in either of the two tests (core- or envelope-protein CIA) was considered to be a positive verification of the presence of HIV antibodies.

Western blot. The western blot analysis was performed as described $[17,18]$. Three stand wa rols were used in all weste control (serum from aclichically assurs: a nealthy individual), a positive control (serum from a patien with AIDS), and a diluted positive sample. The western blots were interpreted as positive if specific staining of viral proteins having molecular weights of 24 kilodaltons (kDa) and $41 \mathrm{kDa}$ was observed. Alternatively, the blots with specific staining of either gp 4 or p24 proteins in addition to proteins at $55 \mathrm{kDa}$ and $65 \mathrm{kDa}$ were also interpreted as positive. Samples with reactivity at $24 \mathrm{kDa}$ or $41 \mathrm{kDa}$ only were de fined as indeterminate.

Mouse monoclonal CIA. A CIA system based on mouse monoclonal antibodies to HIV was developed to test specimens for which results by western blot and CIA did not agree. This system used the same components as the CIA described above. except that HRP-labeled mouse monoclonal antibodies to p24 or gp41 were substituted for the HRP-labeled human HIV antibodies. The monoclonal antibodies used were uniquely reactive with their corresponding native or recombinant protein targets [19]. Because of the high degree of specificity of the monoclonal antibodies, the monoclonal CIA coul be expected to eliminate the false-positive reactions in the polyclonal CIA system.

Test specimens. Blood specimens from normal Test specimens. Blood specimens from normal
volunteer blood donors, patients with diseases unrelated to HIV infection, patients with AIDS, pa- tients with AIDS-related complex (ARC), and blood donors seropositive for HIV were evaluated. The donor specimens (blood or plasma) positive for HIV were sent to Abbott Laboratories from various blood banks throughout the United States. This group conreactive specimens in the HTLV-III screening test [20] obtained from United States. All samples were tested under code.

Resullts

Population studies. Sera or plasma from various populations of subjects, including patients with AIDS, patients with ARC, blood donors seropositive for HIV, and unselected blood donors, were screened with the Abbott HTLV III ELISA (before its recent modification) and with the CIA test system for antibodies to HIV antigens (table 1). Western blots were performed on those specimens that were repeatably reactive in either the Abbott HTLV were repeatably reactive in either the Abbott HTLV III ELISA or the CIA test system. Sixty-seven spec-
imens from patients with AIDS were tested; all were imens from patients with AIDS were tested; all were positive by the CIA, whereas $66(98.5 \%)$ of 67 were positive by the ELISA. Only $49(73.1 \%)$ of the 67 were clearly positive by western blot when tested unnegative. Of the 1186 donor specimens positive by screening for HIV that had been sent to the Abbot reference laboratory for confirmatory testing, 31 were positive both by western blot and by the CIA; 844 were negative by bosh ing 31 specimens were positive by CIA but negative or indeterminate by western blot.

Two of 1667 specimens from unselected blood donors were repeatably reactive by the screening test. Neither of these two samples was positive by CIA or western blot, and they were considered to. have had false-positive results. In addition, one of the 1667 samples was positive by CIA but negative by both the screening test and by western blot. This sample was also considered to have false-positive results. Western blots were run only on those samples that were positive by either the screening test or the CIA Specimens from 92 patients with diseases unSped to HIV infection, including 9 patients with red 20 patiens with, including 9 patients with atopy, 20 patients with rheumatoid arthritis, $37 \mathrm{pa}$ thents with leukemia, 20 patients with systemic lupus erythematosus, and 6 patients with infectious mononucleosis were evaluated, 90 of these were nega tive by the screening test, and all 92 were negative Table 1. Presence of HIV antibody, as determined by
Abbott HTLV III EIA, western blot, and CIA.

Test

Subject group (no.

specimens tested) Abbott HTLV Western
III EIA* Patients with AIDS (67) Blood donors. (1186) (1667)

Patients with other
diseases (92) $49(12) \quad 6$ 0 (1)

NOTE. Data are given as no. of samples with positive results. Data for western blot are given as no. positive (no. indeter-

* We used results from the Abbott screening ELISA before was modified in 1987 to improve its specificity and sensitivy: EIA, enzyme immunoassay.

by the CIA. The two samples that were reactive by the screening test were negative by western blot and were considered to have had false-positive results by the screening test.

Evaluating discrepant samples. All of the specimens that were positive by western blot were positive by the CIA system (table 1). Those samples that were negative or indeterminate by western blot bu positive by the CIA system were also positive by a CIA that used HRP-labeled mouse monoclonal antibodies to gp41 or p24 instead of human IgG (data not shown). In addition, 25 donor samples that were negative or indeterminate by western blot and positive in the CIA, were tested for antibodies by a posimmunoprecipitation assay (RIPA) using purified, radiolabeled op 41 or p24. Fourteen of the 25 samples were positive by RIPA for antibodies to p24, whereas all were positive for antibodies to gp41 (data not shown)

Sensitivity studies on diluted samples. Serum samples from patients with AIDS; patients with $\mathrm{ARC}$; and asymptomatic, healthy homosexual men were serially diluted by factors of two in normal serum. Each dilution was tested by the screening test, CIA, and western blot (table 2). The mean endpoin titer (greatest dilution yielding a positive result) of tera tested by CIA for the envelope protein was 25 28 -fold higher tan hat obtain cost moto These titers were also 5.6- to 23 -fold greater than titers obtained with the first-generation screening EIA; the more recent, modified Abbott test has core antibodies was less sensitive than that for the 
Table 2. Endpoint titers for specimens, as determined by the ELISA screening test, CIA, and western blo

\begin{tabular}{lcccc}
\cline { 2 - 4 } $\begin{array}{l}\text { Subject group } \\
\text { (no. of samples) }\end{array}$ & \multicolumn{2}{c}{ CIA using indicated protein } & \\
\cline { 2 - 4 } Patients with AIDS (6) & Screening test* & Envelope & Core & Western blot \\
Patients with ARC (3) & $88(16-256)$ & $939(512-2048)$ & $11(0-64)$ & $117(4-512)$ \\
Asymptomatic persons (5) & $299(128-512)$ & $6327(4096-8192)$ & $171(0-512)$ & $234(64-512)$ \\
\hline
\end{tabular}

NOTE. Data are given as mean (range). Reciprocal titer is defined as the inverse of the highest dilution at which any virus-

* Results were obtained with the first Abbott ELISA screening test.

antibodies to the envelope protein and was approximately equal in sensitivity to the screening test and western blot for detecting HIV antibodies in patients with ARC and in asymptomatic individuals. The CIA for the HIV core antibodies was, however, less effective than the other tests in detecting antibodies in patients with AIDS.

Distribution of CIA results. All sera from patients with AIDS and from blood donors positive for HIV by western blot were positive for antibot es to either envelope or core positing antibodby th CIA. Anibodies to the by the CIA. Antibodies to the envelope recombinant protein were detected in $>98 \%$ of individuals with various stages of $\mathrm{HIV}$ infection who were positive for antibody (table 3). In contrast, antibodies to core proteins were detected in $65 \%-72 \%$ of blood donors or patients with ARC, but were detected in only $21 \%$ of patients with AIDS.

Discussion

Because the screening tests for blood donors are designed for greater sensitivity than specificity, falsepositive reactions would be expected. Presently, any unit of blood that is repeatably reactive by the screening procedure is withdrawn from the donor pool and subjected to an alternate test to confirm the pressubjected to an alternate test to confirm the pres-

fied of their seropositivity only if the result of the alternate test is positive; this second test gives an added level of confidence in the accuracy of interpretation. The western blot has been the alternate immunoassay most commonly used to confirm the presence of HIV antibody in specimens that are repeatably reactive by the screening test. The adve

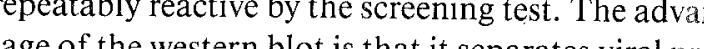
lage cific HIV pocins can be idhat antibodies to specific HIV proteins can be identified, with particular Wention given to antibodies to p24 and gp41 [21] Western blot can be as sensitive as the screening procedure, but the method requires a subjective interpretation. Moreover, the western blot uses viral preparations from the same source as those used in the screening test and it uses a test principle similar to that for the screening test; thus, false-positive results may recur during the confirmation test. In particular, the nonspecificity of antibody reactions at single bands on western blot is not uncomion $[5-8]$. Such reas on [5-8]. Such neacions often bom par the with those of virat at poins and have resulted in the need for more ing an asymptomatic HIV infection. Consequently most laboratories using the western blot as a confirmatory test require detecting reactions at more than one band on the blot for a result to be interpreted as positive.

Table 3. Distribution of antibodies to envelope and core proteins in specimens tested at Abbott Laboratories, by CIA Percent positive for antibodies to

Subject group

Core ${ }^{\dagger}$ Env and core Env $^{+/ \mathrm{Core}^{-}} \mathrm{Core}^{+} / \mathrm{env}^{-}$

Seropositive blood donors $(342)$

Patients with ARC (43)
Patients with AIDS (67) Env and/or core

100

NOTE. Env, envelope proteins; Core, core protein; +, positive; and - , negative,

+ "Env" column represnts env" and core or core-
Our first solid-phase confirmatory procedure consisted of a CIA system with whole-virus lysate being used as a target antigen [20]. Although this assay was successful, it did not provide specific information identifying which viral proteins were being recognized. We determined that the independent determination of antibodies such as those to 24 and deterinit we gp41 would be neded among the criteria for a confirmation procedure, and the sensitivity of one or both of these determinations should be equal to or greater than that of the screening test and comparable with that of the western blot. In addition, the procedures should be objective and standardized and should preferably use both an antigen source and a test principle that are different than those used in the screening test. The combination of the two CIAs using recombinant-derived antigens from the envelope and core proteins of HIV met these criteria. The high specificities of the CIAs provided a level of confidence high enough that a duplicate positive reaction obtained by using one of the two CIAs together with a positive reaction from a screen

The sensitivity of the screening tests for antibodies to HIV was first defined by the percentage of test results that were positive in a population of specimens from a population of patients with AIDS. In the present study, all 67 specimens from patients with AIDS were positive by the CIA, whereas one or more of these specimens was missed by the screening test or by western blot (table 1) when tested blindly in a routine diagnostic laboratory. A second indicator of sensitivity is the ability to detect all samples positive by western blot. In the present study, all 360 specimens positive by western blot, including those from ins 311 cons as positive by the CIA (table 1). In addition, 31 samples from donors and 17 samples from patients with AIDS that were positive by the screening test but were indeterminate (one band) or negative by western blot were positive by the CIA. The specificity of these reactions in the CIA was evaluated; results indicated that they were true positives.

Sensitivity has also been evaluated by determining the endpoint titers of known positive samples. Serial dilutions of specimens from asymptomatic donors should carry more weight than those from patients with AIDS in evaluating a test that will be ped prina $A$ in a in evad bank setting. The CIA system procer either the screening test or western blot for both spec- imens from patients with AIDS and from donors (table 2). After these data had been generated, Abbo modified its screening ELISA to improve specificity, and sensitivity was also increased by about two dilutions. Even so, the CIA procedure remains twoto fourfold more sensitive than the screening test, and it is more sensitive, by several twofold dilutions, than a western blot procedure that is routinely used in confirmation testing.

Specificity for the first screening procedures for HIV antibody was defined in terms of the percentage of nonreacting persons in a population of low-risk donors $[20,22]$. By this definition, the specificity of the CIA system described here is $99.95 \%$ (table 1). Furthermore, false-positive results that might occur with the CIA may be of a different biologic or physical nature than those obtained with the screening test, because the two tests differ in both antigen source and test principle. Western blot has been the accepted standard of specificity. In this study, however, there were 48 specimens that were positive by the CIA but negative or indeterminate by western the CIA but negaivecor indern of ef these samples were from patients with AIDS and must be considered as true positives. The remaining 31 were donor specimens that had been positive in the screening test and were found to be positive by an alternate CIA that used monoclonal antibodies and recombinant antigens as reagents. Twenty-five of the 31 donor specimens were available for testing by RIPA [23, 24], and all were positive for antibodies to gp41, p24, or both. Thus the probability that the results for these 48 specimens are true positives is high. Therefore the specificity of the CIA is established both for populations positive by the screening test and for those negative by the screening ing correctly idenified all true-positive se, the a proble idc saled all true-positive sera and all problematic samples in the group of negative sera turer's recommendations [25].

A potential disadvantage of the CIA system is that the recombinant proteins were derived from selected portions of the HIV genome and may not have detected all of the individuals who were truly positive for antibodies, as can be detected with the wholevirus lysate. Our data indicate, however, that all truepositive samples, including those from patients with AIDS and those from blood donors whose blood 
were equally positive when tested by methods using antigens from the purified virus or recombinant proteins (tables 1 and 2). In other studies, successful test for antibodies have been developed by using either recombinant proteins [26-29] or synthetic peptide [30] derived from the env gene or by using recombinant proteins derived from the gag gene [31].

In the present study and in European studies using this CIA [25, 32], $98 \%$ or more of the samples positive by CIA were detected with the envelope recombinant protein, regardless of the stage of infection (table 3). This finding is in agreement with other studies that have inc envelope proins of Hivinfection $[33-37]$. There is no clear explanation why a few specinens were negative for envelope antibodies but were positive for core antibodies. We have identified two specimens that gave falsenegative reactions; these appeared to be caused by rheumatoid factor. We have subseqently modified the test reagents to correct for the phenomenon [36] It is also possible that false-positive results could occur for specimens from subjects infected with HIV2 [38], but this possibility cannot be confirmed presently.

By the CIA using the core antigens, $\sim 66 \%$ of the 342 samples from blood donors confirmed positive for antibodies to HIV and $72 \%$ of the 43 patients with ARC were reactive, yet only $21 \%$ of 67 samples from patients with AIDS were positive for antibodies to core antigen (table 3). Other studies using this CIA also indicate that the detectability of antibodies to core proteins declines in the later stages of infection [39-41]. This observation is verified by several studies using other immunoassay systems [18, $23,42-44]$. It has become apparent that the loss of antibody to core proteins is often associated with HIV p24 antigenemia $[40,41]$ and with a worsening prognosis Additional studies will be required tablish the value of the CIA and HIV-antigen tests.

References

1. Consensus Development Panel. The impact of routine HTLV II antibody testing of blood and plasma donors on public health. JAMA 1986;256:1778-83

2. Ward JW, Grindon AJ, Feorino PM, Schable C, Parvin M, Allen JR. Laboratory and epidemiologic evaluation of enzyme immunoass

3. Kuihnl P, Seidl S, Holzberger G. HLA DR4 antibodiescinse positive
4. Hunter JB, Menitove JE. HLA antibodies detected by EL ISA HTLV III antibody kits. Lancet 1985;2:397

positive HTLV-III western blot. N Engl J Med with a false 6 Biberfeld G, Bredberg-Raden U, Bottiger B, Putkonen P0 Blomberg J, Juto P, Wadell G. Blood donor with false poit 作 virus. Lancet 1985;2:289-90

van der Poel CL, Reesink HW, Tersmette T, Lelie PN, Hu man $\mathrm{H}$, Miedema F. Blood donations reactive for HIV western blot, but non-infective in culture and recipients

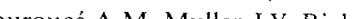

作 blood donors. Lancet 1986;2:921-2

. Dawson GJ, Heller JS, Decker RH, Valdivia L. A confirm tory assay for antibodies to HTLV-III [abstract 642] In Program and abstracts of the $2 \mathrm{~d}$ International Conferesce on AIDS. Geneva: World Health Organization, 1986 Sambrook J. Molecular cloning. A laboratory manual. Cold Spring Harbor, NY: Cold Spring
Harbor Laboratories, 1982 Blatner FR, Williams BG, Blect, A K, Faber HE, Furlong L-A A Gunuld DJ-Thompson Moore DD, Schumm JW, Sheldon EL, Smithies O Ch ron phages: safer derivatives of bacteriophage lambda for DNA cloning. Science 1977;196:161-9

12. Wood C, Kieselburg M, Andersen P, Devare S. Molecular studies of human $T$ cell leukemia virus-III [abstract]. Cell Biochem [Suppl] 1985;9A:94

HTIV Andersen PNA, Devare S. Cloning and expression of Cold Spring tumor viruses. Cold Spring Harbor, NY Stahl S, Mackay P, Magazin M, Bruce SA, Murray K. Hepa tits B virus core antigen: synthesis in Escherichia coll an $1606-10$

5. Decker RH, Overby LR, Ling C-M, Frösner G, Deinhard F, Boggs J. Serologic studies of transmission of hepatitis A in humans. J Infect Dis 1979;139:74-82

A Kawaaoi A. Peroxidase-labeled antibody. A new 1084-91

17. Towbin H, Staehelin T, Gordon J. Electrophoretic transfer of proteins from polyacrylamide gels to nitrocellulose sheets: procedure and some applications. Proc Natl Acad Sci USA 1979;76:4350-4

18. Schüpbach J, Haller O, Vogt M, Lüthy R, Joller H, Oelz O Popovic M, Sarngadharan MG, Gallo RC. Antibodies to HTL-III in Swiss patients with AIDS and pre-AIDS and

9. Hunt JC, Webber JS, Wray LK, Kieselburg DO Dawon GJ, Casey JM, Andersen PR, Wood CA, Devare SG. Mou, monoclonal antibodies to HTLV-III structural proteins fabstract]. J Cell Biochem [Suppl] 1986;10A:190

20. Barrett JE, Dawson G, Heller J, Bairstow C, Fico R, Webber JS, Gutierrez R, Decker RH. Performance evaluation of the Abbott HTLV III EIA, a test for antibody to HT III in donor blood. Am J Clin Path 1986;86:180-5

vice inter-agency recomol. Provisional Public Health Ser- blood and plasma for antibody to the virus causing acquired immunodeficiency syndrome. MMWR 1985;34:1-5 lymphotropic virus type IIII. Sensitivity and specificity. Ann Intern Med 1985; 103:726-

23. Casey JM, Kim Y, Andersen PR, Watson KF, Fox JL, Devare SG. Human T-cell lymphotropic virus type III: immunologic characterization and primary structure analy
sis of the major internal protein, 24 . J Virol 1985:55:417-23

24. Markwell MAK. A new solid state reagent to iodinate proConditions for the efficient labeling of anticerum. Anal Biochem 1982;125:427-32

25. Deinhardt F, Eberle J, Gurtler L. Sensitivity and specificity of eight commercial and one recombinant anti-HIV ELISA tests. Lancet 1987;1:40

26. Cabradilla CD, Groopman JE, Lanigan J, Renz M, Lasky LA, Capon DJ. Serodiagnosis of antibodies to the human peptide. Biotechnology 1986:4:128-33

27. Chang TW, Kato I, McKinney S, Chanda P, Barone AD, Wong-Staal F, Gallo RC, Chang NT. Detection of antibodies to human T-cell lymphotropic virus-III (HTLV-III) with an immunoassay employing a recombinant Escherichia coli-derived viral antigenic peptide. Biotechnology

28. Crowl R, Ganguly K, Gordon M, Conroy R, Schaber M, Kramer R, Shaw G, Wong-Staal F, Reddy EP. HTLV-III entios 1985;41:979-86

29. Schulz TF, Aschauer JM, Hengster P, Larcher C, Wachter H, Fleckenstein B, Dierich MP. Envelope gene-derived recombinant peptide in the serodiagnosis of human immunodeficiency virus infection. Lancet 1986;2:111-2

30. Kennedy RC, Henkel RD, Pauletti D, Allan JS, Lee TH, Essex M, Dreesman GR. Antiserum to a synthetic peptide recognizes the HTLV.

31. Dowbenko DJ, Bell JR, Benton CV Groopman JE, Nguyen H, Vetterlein D, Capon DJ, Lasky LA. Bacterial expression of the acquired immunodeficiency syndrome retrovirus p24 gag protein and its use as a diagnostic reagent. Proc Natl Acad Sci USA 1985;82:7748-52

32. Habermehl KO, Zorr B, Deinhardt F, Gurtler L, Koch MA Maass G, Hopken W, Knocke KW. Specificity and sensitivity of ant-HTLVII/LAV determinations with a recom-

33. Sarngadharan MG Popovic M, Bruch L, Schüpbach J, Gallo RC. Antibodies reactive with human T-lymphotropic retroviruses (HTLV-III) in the serum of patients with AIDS. Science 1984:224:506 :8

34. Kitchen LW, Barin F; Sullivan JL, McLane MF, Brettler DB,
Levine PH, Essex M. Aetiology of AIDS-antibodies to human T-cell leukaemia

35. Allan JS, Coligan JE, Barin F, McLane MF, Sodroski JG, Rosen CA, Haseltine WA, Lee TH, Essex M. Major gly coprotein antigens that induce antibodies in AIDS patients

Decker RH, Dawson GJ. Recombinant antigens as diagnostic and screening reagents for HIV infections: experience
with a commercial test. In: Luciw PA, Steimer KS, Overby LR, eds. Genetic engineering approaches to AIDS diagnosis. New York: Marcel Dekker, 1987 (in press)

37. Barin F, McLane MF, Allan JS, Lee TH, Groopman JE, Essex M. Virus envelope protein of HTLV-III represents major target antigen for antibodies in AIDS patients. Science 1985;228:1094-6

Kanki PJ, Barin F, M'Boup S, Allan JS, Romet-Lemonne JL Marlink KR, McLane MF, Lee T-H, Arbeille B, Denis to simian T-lymphotropic virus type III. Science 1986.232. $238-43$

39. Frösner GG, Erfle V, Mellert W, Hehlmann R. Diagnostic significance of quantitative determination of HIV anti$159-60$

40. Coudtrit, Lage JMA, Pa, DA, Dawson GJ A A mia and antibody titers to core and envelope antigens in munodeficiency virus infection. J Infect Dis 1987:155 $558-60$

41. Mayer KH, Falk LA, Paul DA, Dawson GJ, Stoddard AM, McCusker J, Saltzman SP, Moon MW, Ferriani R, Groopman JE. Correlation of recombinant antigen and antibody to the human immunodeficiency virus (HIV) with subsequent clinical outcomes in a cohort of asymptomatic ho-

Kascrual males. Am J Med 1987,83:208-12

Kalyanaraman VS, Cabradilla CD, Getchell JP, Narayanan wier L, Spira TJ, Kaplan J, Fishbein D, Jaffe HW, Curran $J W$, Francis DP. Antibodies to the core protein ymphadenopathy-associated virus (LAV) in patients with AIDS. Science 1984;225:321-3

43. Burke DS, Redfield RR, Putman P, Alexander SS: Variation in western blot banding patterns of human T-cell lymphotropic virus type III//ymphade

44. Birear RJ, Melbye M, Ebbesen P, Alexander S, Nielse JO Sarin P, Faber V Variation in human T lymphotropic virus III (HTLV-III) antibodies in homosexual men: decline before onset of illness related to acquired immune deficiency syndrome (AIDS). Br Med J 1985;291:997-8 